\title{
PEMAHAMAN DAN PENGAMALAN SURAT AL JUMUAH AYAT 9-10 (STUDI KASUS PADA PEDAGANG DI LINGKUNGAN MASJID AMPEL SURABAYA)
}

\author{
Fahmi Abdullah \\ Mahasiswa Program Studi S-1 Ekonomi Islam - Fakultas Ekonomi dan Bisnis - Universitas \\ Airlangga \\ Muhammad Nafik HR \\ Departemen Ekonomi Syariah - Fakultas Ekonomi dan Bisnis - Universitas Airlangga \\ Email: manhard999@yahoo.com
}

\begin{abstract}
This study analyzes understanding of merchants of surah Al Jumuah verses 9-10. Understanding that examined about when sounding the call Athan all activities (sale and purchase) must be abandoned immediately and promptly carry out the Friday prayers, and back doing activities (sale and purchase) when finished doing the prayer Friday. This research used the qualitative approach with case studies. Data collection was done with interviews and observations directly to the object/subject of research. The results of this research show that the level of understanding of respective merchants of surah Al Jumuah verses 9-10 good and different so that the impact on the implementating. In addition, they believe in running the prayer Friday positively impact of sustenance, though not directly. A positive impact not only sustenance, but by hearing sermons Friday prayers will add to the sense of faithfulness to God Almighty.
\end{abstract}

Keyword: Understanding, Implementation, surah Al Jumuah verses 9-10, Merchants

\section{PENDAHULUAN}

\section{A. Latar Belakang}

Kewirausahaan (entrepreneurship) merupakan sektor penting dalam menyumbang pertumbuhan ekonomi suatu negara. Kemajuan atau kemunduran ekonomi suatu bangsa sangat ditentukan oleh keberadaan dan peranan dari kelompok wirausahawan ini (Rachbini, 2002:14). Kewirausahaan dapat membantu menyediakan begitu banyak kesempatan lapangan pekerjaan, berbagai kebutuhan konsumen, jasa pelayanan, serta menumbuhkan kesejahteraan dan tingkat kompetisi suatu negara. Di Indonesia jumlah wirausaha masih sangat rendah jika dibandingkan dengan negara-negara lain. Jumlah tersebut dapat di lihat pada Tabel 1 sebagai berikut;

\section{Tabel 1}

Presentase Wirausaha Terhadap Jumlah Penduduk di Dunia Tahun 2011 Sumber : Diolah dari berbagai Sumber. (BPS dan Elfindri dkk).

\begin{tabular}{|l|l|l|}
\hline Negara & Penduduk & Persentase \\
\hline Amerika & 293 juta jiwa & $12,5 \%$ \\
\hline Jepang & 127 juta jiwa & $10 \%$ \\
\hline Inggris & 60 juta jiwa & $10 \%$ \\
\hline Singapura & 4 juta jiwa & $7,5 \%$ \\
\hline China & 1.298 juta jiwa & $2,5 \%$ \\
\hline India & 1.065 juta jiwa & $2,5 \%$ \\
\hline Malaysia & 23 juta jiwa & $2,5 \%$ \\
\hline Indonesia & 240 juta jiwa & $0,2 \%$ \\
\hline
\end{tabular}

Berdasarkan tabel di atas menunjukkan bahwa bila $0,2 \%$ dari total penduduk Indonesia atau sebesar 440 ribu orang merupakan wirausahawan maka jumlah ini sangatlah kecil dalam skala ekonomi. Apalagi untuk ukuran negara 
sebesar Indonesia dengan tingkat sumber daya alam yang besar. Indonesia membutuhkan setidaknya $2 \%$ dari total penduduk untuk bersaing dalam perekonomian global. (Elfindri dkk., 2010:12).

Berwirausaha merupakan aktifitas yang berhubungan dengan ajaran Islam, seorang wirausaha muslim yang mencari rezeki sebaiknya mengamalkan ayat ini. Menurut analisa C.C Torrey dalam bukunya yang berjudul The Commercial Theological Terms in The Qur"an (Khutbah, 2010:2) menyebutkan bahwa teologi Islam adalah Teologi Perdagangan. Lebih lanjut la mengatakan:

"Hubungan-hubungan timbal balik antara Tuhan dan manusia adalah bersifat perdagangan betul. Allah adalah saudagar sempurna. la memasukkan seluruh alam semesta dalam pembukuannya. Segalanya diperhitungkan, neraca-neraca dan la telah menjadi contoh buat bisnis- bisnis yang jujur. Hidup adalah suatu bisnis, orang untung atau rugi disitu. Bagi yang melakukan pekerjaan baik atau jahat lyang mencapai kebaikan atau kejahatan) akan mendapat ganjaran, malahan juga dalam hidup ini juga. Hutang-hutang tertentu dihapuskan, sebab Allah bukanlah penghutang yang tidak berbelas kasihan".

Kewajiban pokok setiap orang adalah shalat, sebab didalamnya terdapat keyakinan dan pernyataan ketundukan kepada Allah, namun setelah shalat itu ditunaikan maka bekerja adalah wajib karena disitulah diwajib membetulkan timbangan, bersikap jujur, lemah lembut dalam berjual beli, sebagai konsekuensi keyakinan dan pernyataan ketaatan kepada Allah.

Pembebanan untuk melaksanakan ibadah menjadi suatu kewajiban, sampai dirinya berjumpa dengan Tuhannya. Ibadah shalat Jum"at itu tidak bisa ditinggalkan dengan alasan apapun, kecuali ada hal-hal tertentu yang sangat mendesak sehingga ada keringanan untuk melaksanakannya. Dalam sebuah hadits Nabi bersabda:

ضيرم وأ ،يبص وأ ،ةأرما و أ ،كو همم دبع :تعبر أ إ تعامج يف مهسم مك هـع بجاو كح تعمجنا

"Shalat Jum"at itu wajib atas tiap orang muslim berjama"ah kecuali empat orang: hamba sahaya, wanita, anak-anak atau orang sakit" (HR. Daud dan Al-Hakim).

Begitu pentingnya urusan dunia dan urusan akhirat, sehingga manusia diharuskan mengerjakan kedua kewajiban tersebut bersama-sama dan tidak terbebani atasnya. Namun kadangkadang manusia lebih mementingkan mencari sesuatu yang nampak dan dapat dirasakan saat ini.

Masjid Ampel merupakan pusat ibadah dan pusat dakwah Islam yang dirintis oleh Sunan Ampel, kawasan ini menjadi penting sebagai tempat ibadah atau kawasan religi, pusat pendidikan kelslaman, serta sarana pemukiman dan pariwisata religius. Keberadaan Masjid Ampel pusat penyebaran agama Islam 
menjadikan kawasan Ampel ditetapkan pemerintah sebagai pusat wisata religi di Surabaya. Pada kawasan Ampel terdapat beberapa wisata religi seperti Masjid Ampel, Makam Sunan Ampel, Makam KH Mas Mansyur, Makam Boto Putih dan Pasar Sasak Ampel Suci.

Bulan Ramadhan (menjelang idul fitri) dan bulan Haji (Idul Adha) kawasan Ampel menjadi sangat padat oleh pendatang dari berbagai daerah. Jumlah pengunjung bahkan bisa lebih banyak hingga dua kali lipat jika dibandingkan dengan hari biasa. Hal ini disebabkan karena budaya di Indonesia khususnya umat Islam bulan Ramadhan (menjelang Idul Fitri) identik dengan „bermalam" di Masjid dan menjelang Idul Fitri berbelanja dan memberi oleh- oleh kesanak famili dalam bentuk perlengkapan sholat, minyak wangi maupun baju baru. Pada bulan Haji (Idul Adha) kebanyakan orang yang pulang dari haji mempunyai kebiasaan memberikan oleh-oleh kepada tamu yang mengunjungi.

Kawasan Ampel dihuni oleh penduduk etnis Jawa, etnis Cina, etnis Madura dan keturunan Arab atau Timur Tengah. Komunitas keturunan Arab atau Timur Tengah sangat mendominasi kawasan Ampel, karena itu orang dengan perawakan khas Timur Tengah banyak terdapat di kawasan Ampel. Banyak diantara pedagang yang menjual barang-barang yang bernuansa Timur Tengah mulai dari minyak wangi, perlengkapan haji, kurma, kitab-kitab pondok, kitab Beirut dan Alquran. Tidak hanya itu saja, nuansa Timur Tengahnya begitu terasa dengan banyaknya dagangan masakan khas Timur Tengah seperti nasi kebuli, roti maryam, kambing oven dan makanan-makanan yang berbau Timur Tengah lainnya. Keberadaan warga keturunan Arab di kawasan Ampel tidak terlepas dari sejarah Sunan Ampel, yang merupakan keturunan Arab. Berikut jumlah pedagang di kawasan Sasak

\section{Tabel 2}

\section{Jenis Usaha dan Jumlah Toko di Kawasan Sasak Surabaya tahun 2013}

\begin{tabular}{|l|l|l|}
\hline No & Usaha & Jumlah \\
\hline 1 & Busana Muslim/ perlengkapan & 45 Toko \\
\hline 2 & Sarung & 3 Toko \\
\hline 3 & Kopyah & 5 Toko \\
\hline 4 & Minyak wangi & 7 Toko \\
\hline 5 & Kitab-kitab Islam & 24 Toko \\
\hline 6 & Kurma & 3 Toko \\
\hline 7 & Alat tulis kantor & 4 Toko \\
\hline 8 & Krudung & 1 Toko \\
\hline
\end{tabular}

Sumber: Hasil Observasi (2014)

Pedagang di lingkungan masjid Ampel sangat padat dan disibukkan dengan kegiatan jual beli ketika peziarah atau pembeli yang ingin berbelanja. Dengan keadaan seperti ini, pedagang bisa melupakan atau menunda urusan ibadah terutama ibadah sholat Jumat, yang mana pedagang tersebut beralasan terlalu sibuk sehingga tidak menjalankan ibadah shalat jumat. Namun hal ini sesuai dengan tuntunan Al Quran yang mengharuskan untuk berhenti bekerja ketika waktu ibadah umat muslim telah datang yakni ibadah sholat jumat, 
sebagaimana dijelaskan dalam surat Al Jumuah ayat 9-10 menjelaskan tentang dianjurkannya meninggalkan aktifitas apapun bahkan jual beli ketika panggilan adzan sholat Jum"at dan segera melaksanakan sholat Jumat, jika telah selesai melaksanakan ibadah sholat Jumat maka bertebarlah untuk mencarilah karunia Allah (bekerja) dan selalu berdzikir ketika bekerja maupun tidak bekerja.

Melihat kondisi pedagang yang bekerja di sekitar masjid Ampel tersebut, yang cenderung disibukkan dengan kegiatan jual beli apabila sedang ramai serta para peziarah yang sedang berbelanja di sekitar masjid Ampel Surabaya. Dari fenomena tersebut peneliti tertarik untuk mengadakan penelitian terhadap pemahaman dan pengamalan surat $\mathrm{Al}$ Jumuah ayat 9-10 pada pedagang di lingkungan masjid Ampel Surabaya.

\section{HASIL PENELITIAN DAN PEMBAHASAN}

\section{A. Bertawakkal Kunci Mencari Rezeki}

Al-Ghazali (2008:380) menjelaskan bahwa tawakal adalah bergantung kepada Allah dalam segala urusan. Seseorang yang bertawakal adalah seseorang yang menyerahkan, mempercayakan dan mewakilkan segala urusannya hanya kepada Allah (Maulan, 2010). Dalil syar"i yang menjelaskan bahwa bertawakal kepada Allah termasuk kunci rezeki. Firman Allah dalam surat Ath Thalaaq ayat 3

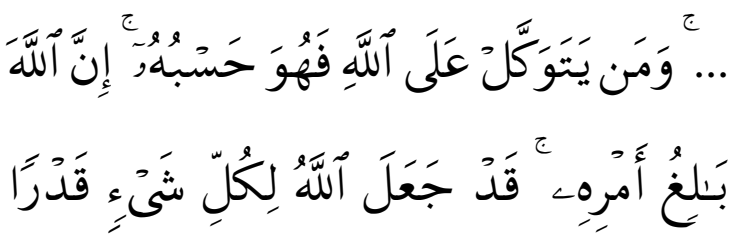

"...Dan Barangsiapa yang bertawakkal kepada Allah niscaya Allah akan mencukupkan (keperluan)-nya. Sesungguhnya Allah melaksanakan urusan yang (dikehendaki)-Nya. Sesungguhnya Allah telah Mengadakan ketentuan bagi tiap-tiap sesuatu". (QS. Ath Thalaaq (65):23)

Bertakwa artinya orang-orang beriman yang mematuhi atau mengikuti semua peraturan- peraturan Allah dengan baik, sempurna, tidak setengah setengah, ikhlas dan juga menjauhi semua laranganlarangan yang diberitahu oleh Allah maka Allah akan mencintainya dan mempercayainya untuk mengatur kekayaan Allah yang ada di bumi ini.

Dari Umar bin Khattab ra berkata, bahwa beliau mendengar Rasulullah SAW bersabda,

اناطب حورتو ،اصامخ ودغت ،ريطنا قزري امكك مكلزرن ههكوت كح الله دهع نو هكوت مكنأ ون

Artinya: "Sekiranya kalian benar-benar bertawakal kepada Allah SWT dengan tawakal yang sebenar- benarnya, sungguh kalian akan diberi rizki (oleh Allah SWT), sebagaimana seekor burung diberi rizki; dimana ia pergi pada pagi hari dalam keadaan lapar, dan pulang di sore 
hari dalam keadaan kenyang (HR. Ahmad, Turmudzi dan Ibnu Majah).

Menafsirkan hadits diatas, Maulan (2010) menjelaskan tentang hakekat tawakal yang digambarkan oleh Rasulullah SAW dengan perumpamaan seekor burung. Dimana burung pergi (baca ; mencari karunia Allah) pada pagi hari dengan perut kosong karena lapar, namun di sore hari ia pulang dalam keadaan perut kenyang dan terisi penuh. Karena pada hakekatnya Allah SWT lah yang memberikan rizkinya sesuai dengan kebutuhannya.

\section{B. Bertawakal}

Bukan

Berarti

\section{Meninggalkan Usaha}

Tawakal tidak hanya menyerahkan segala urusan kepada Allah, tetapi juga harus disertai dengan usaha yang sungguh-sungguh dari seorang hamba. Berusaha atau bekerja tidaklah mengeluarkan orang dari garis tawakal. Hal ini senada dengan hadits yang diriwayatkan oleh Imam Ibnu Hibban dan Al-Hakim dari Ja"far Bin Amr Bin Umayyah dari ayahnya (Rich dan Laode, 2012:514), dia berkata: "Seseorang telah berkata kepada Rasulullah SAW, "AkU biarkan untaku dan aku bertawakal." Rasulullah bersabda, "Ikatlah ia dan bertawakallah"." Dalam riwayat AlQudha"i disebutkan, bahwa Amr bin Umayyah (Rich dan Laode, 2012:514) berkata, "'Ya Rasulullah, apakah aku mengikat unta kendaraanku dan bertawakal kepada Allah atau aku melepaskannya saja dan bertawakal?"
Beliau bersabda, "Ikatlah ia dan bertawakallah"."

Dr. Fadhl llahi (Rich dan Laode, 2012:514) berpendapat dalam Mafaatihurrizqi fii Dhauil Kitaab was Sunnah, "Tawakal itu bukan berarti meninggalkan usaha. Justru seoarang Muslim itu dianjurkan untuk berusaha dan bekerja sungguh-sungguh. Hanya saja ia tidak boleh bersandar pada usahanya semata-mata, tetapi ia harus berkeyakinan bahwa segala urusan itu di tangan Allah, bahwa hasilnya adalah keputusan Allah, dan bahwa rezeki itu datang hanya karena kehendak Allah semata."

\section{Hukum Dan Prinsip Dalam Jual Beli Islam}

Jual beli dibolehkan dengan adanya dalil dari Al-Quran, Sunnah, dan ijma ulama (Sa"di dkk., 2008:142). Landasan hukum sebagaimana dalam firman Allah QS. Al Baqarah ayat 275 dan Hadits Nabi yang dikelurkan oleh Imam Bukhari dan Imam Muslim(muttafaqun"alaih) sebagai berikut.

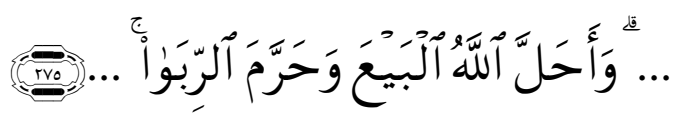

"...Padahal Allah telah menghalalkan jual-beli dan mengharamkan riba..."(QS:2: Al- Baqarah:275)

Hakim bin Hizaam
berkata,"Rasulullah sholallahu,"alaihi wa sallam bersabda,"Penjual dan pembeli keduanya bebas selama belum berpisah atau sehingga berpisah keduanya, jika 
keduanya benar, jujur dan menerangkan, maka akan diberkahi untuk mereka penjualannya, dan bila keduanya saling menyembunyikan dan berdusta maka dihapus berkah jual beli keduanya." (Muttafaqun,,alaih (Baqi, 2003:552-553) ).

Kaum Muslimin sepakat untuk memperbolehkan jual beli selama tidak meninggalkan kewajiban dan jual beli tersebut merupakan jual beli yang sah menurut syari"at (Sa"di dkk., 2008:143).

Syari"at Islam menggariskan beberapa prinsip dasar yang bertujuan mengarahkan hubungan antar manusia tersebut sehingga hubungan tersebut berlangsung di atas prinsip-prinsip yang luhur dan suci sehingga keadilan dapat tercapai (Wibowo, 2010:19). Seorang muslim harus mengetahui hal-hal apa saja yang menyebabkan suatu perniagaan dikatakan haram. Ibnu Rusyud al-Maliki (Badri, 2009) menjelaskan bahwa hal-hal yang menyebabkan suatu perniagaan diharamkan dalam Islam ada enam yaitu pertama, barang yang menjadi obyek perniagaan merupakan barang yang diharamkan. Orang yang memperdagangkan barang-barang haram tidak akan mendapatkan keringanan (dari hukum haram) meskipun dia jujur dan terpercaya, karena perdagangan itu sendiri pada dasarnya sudah mungkar, diperangi oleh Islam dan tidak dibenarkan sama sekali (Qardhawi, 2011:156). Kedua, adanya riba. Ketiga adanya ketidakjelasan (gharar). Keempat, adanya persyaratan yang memancing timbulnya riba dan gharar.
Kelima, Penipuan diharamkan Allah, dalam segala hal dan bila penipuan terjadi pada akad perniagaan, maka tindakan ini menjadikan perniagan tersebut diharamkan. Hakim bin Hizaam berkata, Rasulullah bersabda, "Penjual dan pembeli keduanya bebas selama belum berpisah atau sehingga berpisah keduanya, jika keduanya benar, jujur dan menerangkan, maka akan diberkahi untuk mereka penjualannya, dan bila keduanya saling menyembunyikan dan berdusta maka dihapus berkah jual beli keduanya." (Muttafaq"alaih (Baqi, 2003:552-553)). Dari Abu Hurairah bahwa Rasulullah bersabda,"...Barang siapa yang melakukan penipuan maka ia bukan termasuk golonganku." (HR. Muslim (Asqalani, 2009:355)). Hadist tersebut menerangkan bahwa setiap muslim harus melakukan kejujuran dalam proses perniagaan. Dalam hal ini, setiap penjual harus menjelaskan setiap kecacatan barang kepada pembeli. Namun jika sengaja penjual tidak menjelaskan kecacatan barangnya maka ini termasuk penipuan.

Keenam, Merugikan orang lain. Dari sahabat Abu Hurairah radhiallahu 'anhu ia menuturkan, Rasulullah bersabda, "Janganlah engkau saling hasad, janganlah saling menaikkan penawaran barang (padahal tidak ingin membelinya), janganlah saling membenci, janganlah saling merencanakan kejelekan, janganlah sebagian dari kalian melangkahi pembelian sebagian lainnya, dan jadilah 
hamba-hamba Allah yang saling bersaudara. Seorang muslim adalah saudara orang muslim lainnya, tidaklah ia menzhalimi saudaranyanya, dan tidaklah ia membiarkannya dianiaya orang lain, dan tidaklah ia menghinanya." (Muttafaqun 'alaih (Badri, 2008:86-87)). Diantara bentuk-bentuk perniagaan yang merugikan orang lain ialah: Menimbun barang dagangan, Melangkai penawaran atau penjualan sesama muslim dan Percaloan. Maksud adanya pelarangan transaksi-transaksi tersebut adalah agar tidak ada kerincuan dan tipuan dalam jual beli atau berdagang. Sehingga kedua belah pihak tidak saling dirugikan.

\section{Etika Jual Beli Dalam Berdagang}

Islam sendiri sudah mengatur etikaetika yang harus dilakukan seorang pedagang dalam jual beli. Beberapa etika yang seharusnya dimengerti oleh setiap muslim dalam berdagang (Fairman, 2002:315) yaitu antara lain: pertama, membaguskan niat dalam berdagang, jika berdagang itu diniati untuk menyediakan kebutuhan orang-orang yang memerlukan, menafkahi keluarga, dan sebagai sarana untuk berdakwah, maka hal itu bagaikan berjihat di jalan Allah. Kedua, hendaknya kerinduan terhadap dunia tidak mengalahkan kerinduan akhirat, maka ketika mendengar adzan hendaklah meninggalkan perdagangan untuk melaksanakan kewajiban (shalat). Ketiga, hendaknya membiasakan berdzikir, tidak terlalu rakus terhadap harta.
Keempat, tidak curang dan berbohong dalam perdagangan. Kelima, tidak bersumpah hanya karena barangnya ingin laku padahal ia sudah yakin dan tahu atas kebohongannya, maka hal ini termasuk sumpah palsu. Keenam, tidak boleh mengurangi timbangan atau takaran. Ketujuh, tidak boleh memuji berlebihan terhadap barang yang dijual dari apa yang sebenarnya. Kedelapan, tidak boleh mempersempit jalan jual beli dan hendak tidak mengeraskan suara di jalanan. Kesembilan, rela dengan laba yang sedikit, karena itu akan mengundang kepada kecintaan manusia dan menarik banyak pelanggan dan mendapatkan berkah dan rizki.

Kesepuluh, tidak boleh melakukan amaliyah riba. Kesebelas, tidak menjual barang-barang yang terlarang. Keduabelas, menentukan harga dan proses jual beli yang baik.

\section{E. Hukum Jual Beli Ketika Mendengar Adzan}

Dilarang bagi setiap muslim untuk mengadakan akad perniagaan (jual beli) setelah muadzdzin mengumandangkan azan kedua pada hari Jum"at. Ketentuan ini berdasarkan firman Allah:

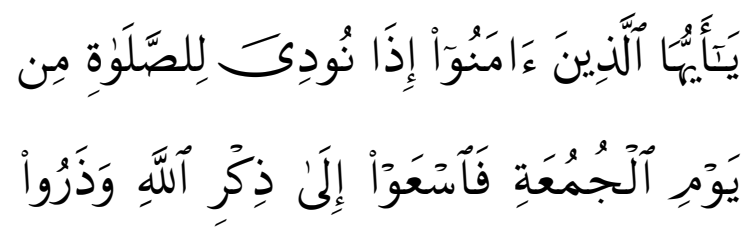




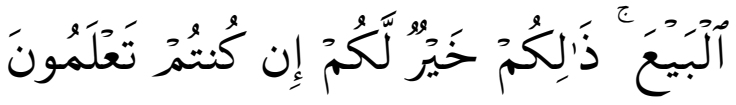

"Wahai orang-orang yang beriman! Apabila telah diseru untuk melaksanakan shalat pada hari Jum'at, maka segeralah kamu mengingat Allah dan tinggalkanlah jual beli. Yang demikian itu lebih baik bagimu jika kamu mengetahui".(QS:62:AlJumu"ah:9)

Muhammad Abdul Tuasikal (2012) berpendapat yang tercakup dalam larangan jual beli yaitu,

1. Para pria yang diwajibkan shalat Jum"at. Sedangkan wanita, anak kecil, dan orang sakit tidak terkena larangan jual beli tersebut. Demikian pendapat jumhur ulama. Alasannya, karena perintah dalam ayat ditujukan pada orang yang pergi Jum"at. Orang selain itu berati tidak terkena larangan jual beli waktu itu.

2. Orang yang melakukannya tahu akan larangan melakukan jual beli setelah azan kedua Jum"at. Demikian pendapat ulama Syafi"iyah

3. Yang melakukan jual beli bukan bermaksud untukk menghilangkan mudhorot (bahaya) sehingga ia terpaksa melakukan jual beli seperti dalam keadaan darurat harus beli makanan atau dalam keadaan darurat harus beli kafan untuk mayit dan jika ditunda, kondisi mayit akan berubah.

4. Jual beli dilakukan setelah adzan Jum"at saat imam naik mimbar. Allah berfirman:

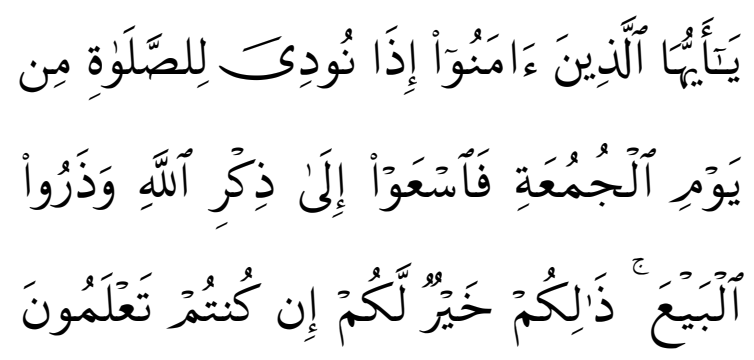

Artinya "Hai orang-orang beriman, janganlah hartamu dan anak-anakmu melalaikan kamu dari mengingat Allah. Barangsiapa yang berbuat demikian Maka mereka Itulah orang-orang yang merugi." (QS Al-Munafiqun:9)

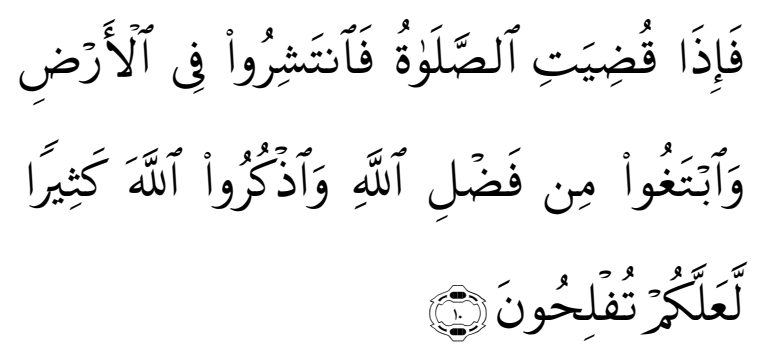

"Apabila telah ditunaikan shalat, maka bertebarlah kamu di bumi; dan carilah karunia Allah dan ingatlah Allah banyakbanyak supaya kamu beruntung." (QS Al Jumuah (62):10).

Ayat diatas menjelaskan untuk melanjutkan jual beli setelah shalat ditunaikan. Ada sebagian riwayat dari sebagian salaf yaitu "Barangsiapa melakukan jual beli setelah shalat Jum"at, maka semoga Allah memberikan ia keberkahan sebanyak 70 kali. Alasannya karena Allah Ta"ala berfirman (yang artinya), „Apabila telah ditunaikan shalat, maka bertebaranlah kamu di muka bumi; dan carilah karunia Allah"". (Tafsir Al 
Qur"an Al „Azhim, Ibnu Katsir, (Tuasikal, 2012)).

Agama telah mewajibkan setiap orang untuk bekerja, sehingga setiap orang yang menganggur meskipun sudah tercukupi semua kebutuhannya, keharusan bekerja tetap ada. Sebab mencari rizki itu adalah kewajiban sebagaimana rosulullah menggambarkan dam sebuah hadits

تضيرفنا دعب تضيرف للاحنا بهط

"Bekerja mencari yang halal itu suatu kewajiban sesudah kewajiban beribadah" (HR.Thabrani dan Baihaqi). Jadi, dapat dikatakan apabila jual beli menyibukkan kamu dari ibadahmu (shalat), maka perdagangan ini dilarang dan sia-sia.

Pemahaman dan Pengamalan Surat Al Jumuah Ayat 9-10
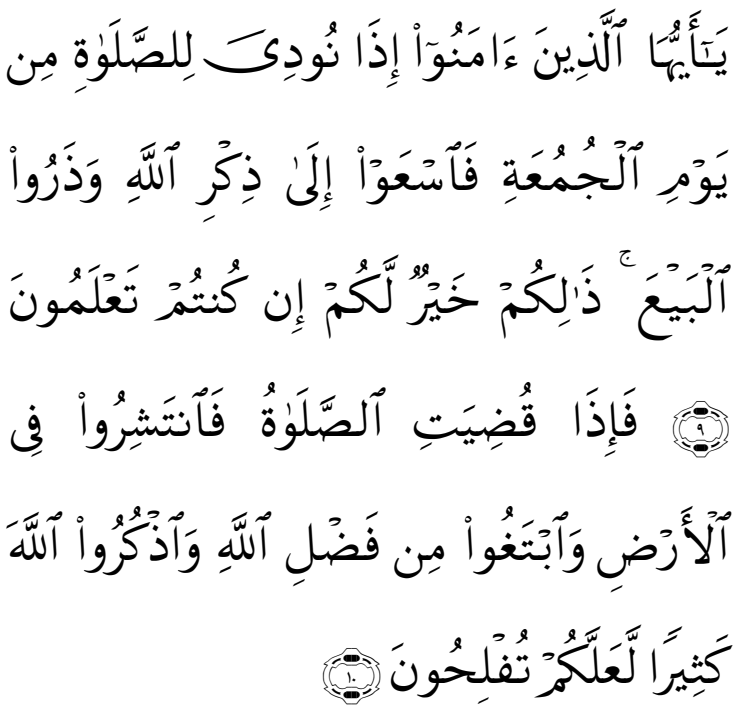

"Hai orang-orang beriman, apabila diseru untuk menunaikan shalat Jum'at, Maka bersegeralah kamu kepada mengingat Allah dan tinggalkanlah jual beli. yang demikian itu lebih baik bagimu jika kamu mengetahui. (10) Apabila telah ditunaikan shalat, maka bertebarlah kamu di bumi; dan carilah karunia Allah dan ingatlah Allah banyak-banyak supaya kamu beruntung." (QS Al Jumuah (62):9-10).

Seorang laki-laki muslim diwajibkan untuk shalat Jum"at, sebab di dalamnya terdapat keyakinan dan pernyataan ketundukan kepada Allah, namun setelah shalat Jum"at itu ditunaikan maka bekerja adalah wajib karena disitulah diwajibkan membetulkan timbangan, bersikap jujur, lemah lembut dalam berjual beli, sebagai konsekuensi keyakinan dan pernyataan ketaatan kepada Allah.

Begitu pentingnya kewajiban urusan dunia dan kewajiban urusan akhirat, sehingga manusia diharuskan mengerjakan kedua kewajiban tersebut bersama-sama dan tidak terbebani atasnya. Namun kadang-kadang manusia lebih mementingkan mencari sesuatu yang nampak dan dapat dirasakan saat ini.

Surat Al Jumuah ayat 9-10 menjelaskan bahwa untuk meninggalkan jual beli apabila telah diserukan panggilan shalat Jum"at, dan kembali bekerja (jual beli) apabila telah dilaksanakan shalat Jum"at. Jika dihubungkan dengan rumusan masalah "Bagaimana pemahaman dan pengamalan surat Al Jumuah ayat 9-10 pada pedagang di lingkungan masjid Ampel Surabaya?" yaitu pengamalan seperti apa yang diamalkan oleh pedagang di lingkungan masjid Ampel Surabaya. 
Pemahaman dan pengamalan memiliki hubungan yang berurutan atau sama lain saling berkesinambungan. Artinya, jika seseorang memahami akan suatu hal, kemudian diikuti adanya pengamalan yang dipraktekkan sebagai bentuk dari pemahaman yang didapatkan sebelumya.

\section{F. Tafsir Surat Al Jumuah Ayat 9-10}

Turunnya ayat ini berkaitan dengan peristiwa pada saat Rasulullah Shallallahu „Alaihi Wasallam berkhutbah pada hariu Jum"at, kemudian datanglah kafilah dagang yang membawa barangbarang dagangan dari negeri Syam (kawasan Palestina sekarang). Mendengar ramai gelaran pameran atau "ekspo" perdagangan dimulai, maka jama"ah Jum"ah yang sedang mendegarkan khutbah dari Rasulullah Shallallahu „Alaihi Wasallam mulai terusik hatinya, antara terus mendengarkan khutbah sampai selesai, atau keluar walau sejenak untuk memesan barang-barang dagangan yang memang sangat diperlukan. Kemudian, ternyata tidak sedikit jama"ah Jum"ah pada waktu itu yang terpaksa keluar untuk menjemput rombongan kafilah dagang dengan meninggalkan mendengar khutbah Jum"ah. Dengan kejadian seperti itu turunlah Q.S Al Jumuah ayat 9-10. Allah SWT berfirman:

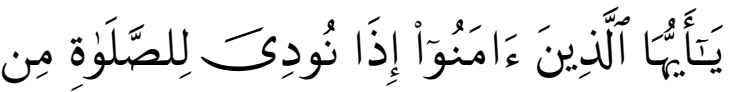

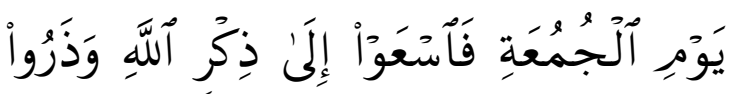

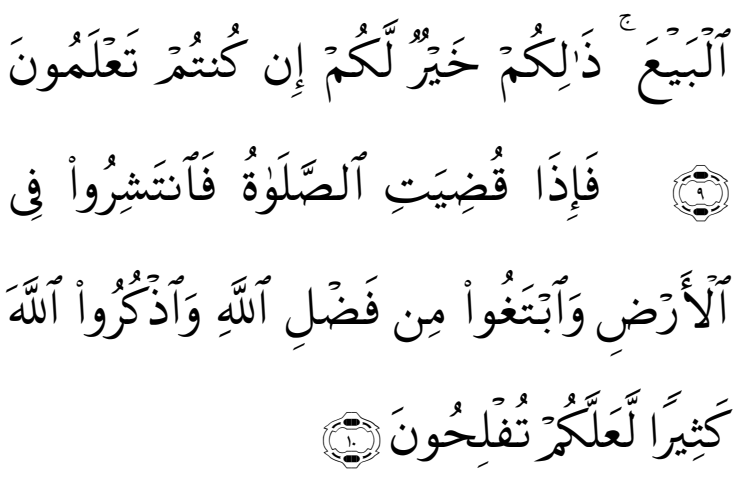

"Hai orang-orang beriman, apabila diseru untuk menunaikan shalat Jum'at, Maka bersegeralah kamu kepada mengingat Allah dan tinggalkanlah jual beli. yang demikian itu lebih baik bagimu jika kamu mengetahui. (10) Apabila telah ditunaikan shalat, maka bertebarlah kamu di bumi; dan carilah karunia Allah dan ingatlah Allah banyakbanyak supaya kamu beruntung." (QS Al Jumuah (62):9-10).

a. Tafsir Ibnu Katsir surat Al Jumuah Ayat 9-10 (Abdullah, 2007)

Dalam penafsirannya Ibnu Katsir termasuk ke dalam tafsir bil ma"tsur yakni menafsirkan Al Quran dengan, sunnah, perkataan sahabat, tabi"in dan kemudian istisyahad dengan berbagai keilmuan untuk mencapai pemahaman yang mendalam. Adapun Langkah-langkah (stratifikasi) penafsiran yang digunakan Ibnu Katsir secara garis besar adalah sebaggai berikut (Yusuf,2004:138): Menafsirkan dengan Al Quran (ayat-ayat lain), menafsirkan dengan hadis, menafsirkan dengan pendapat sahabat dan tabi"in, menafsirkan dengan 
pendapat ulama dan menafsirkan dengan pendapatnya sendiri.

Al Jumuah terambil dari kata AlJam" $U$, yang berarti berkumpul. Karena para pemeluk Islam berkumpul pada hari itu sekali dalam seminggu di tempattempat peribadatan yang besar. Hari tersebut adalah hari keenam di mana Allah menyempurnakan penciptaan semua makhluk. Pada hari itu pula adam tercipta, dimasukkan kedalam Surga, dikeluarkan darinya, dan terjadinya hari kiamat. Pada hari itu terdapat satu saat yang apabila seorang muslim memohon suatu kebaikan kepada Allah, pastilah Allah akan memberikan kebaikan kepadanya, sebagaiman hal ini ditegaskan dalam hadits-hadits shahih. Dalam bahasa Arab kuno, hari Jum"at dikenal dengan nama „Arubah. Telah ditetapkan pula bahwa umat-umat sebelum kita telah diperintahkan untuk melaksanakan ibadah pada hari tersebut, namun mereka lebih memilih kesesatan. Sedangkan orang-orang Yahudi memilih hari Sabtu sebagai hari besar mereka yang bukan pada hari itu Adam diciptakan. Sedangkan kaum Nasrani memilih hari Minggu sebagai hari ibadah mereka. Sedang Allah memilihkan untuk umat ini hari Jum"at, yang pada hari itu Dia telah menyempurnakan penciptaan makhluk. Sebagaimana yang telah diriwayatkan oleh Imam Al Bukhori dan Muslim dari hadits "Abdurrazzaq dari Ma"mar, dari Hamam bin Munabbih, ia mengatakan.
"Inilah yang kami pernah diberitahu oleh Abu Hurairah, di mana ia pernah berkata bahwa Rasulullah bersabda: „Kita adalah orang-orang terakhir yang paling pertama pada hari Kiamat kelak, meskipun mereka diberi $\mathrm{Al}$ kitab sebelum kita. Kemudian sesungguhnya hari ini adalah hari yang Allah telah memberikan kewajiban kepada mereka, lalu mereka berbeda pendapat mengenainya. Maka Allah memberikan petunjuk kepada kita berkenaan dengan hari tersebut. Pada hari itu orang-orang akan mengikuti kita, Yahudi hari setelahnya (besok), sedangkan Nasrani hari setelahnya lagi (lusa)." (HR. Al Bukhari dan Muslim)

Allah telah memerintahkan agar orang-orang yang beriman berkumpul untuk beribadah kepada-Nya, di mana Dia berfirman:

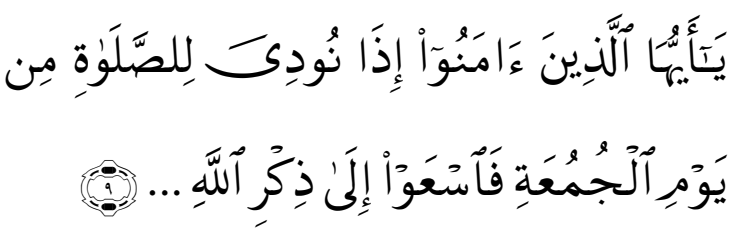

"Hai orang orang yang beriman, apabila diseru untuk menunaikan shalat pada hari Jum"at, maka bersegeralah kamu kepada mengingat Allah."

Maksudnya, berangkatlah kalian, niatkan dan perhatikanlah dalam perjalanan kalian menuju kesana. Hendaklah berjalan dengan kehusyu"an hati dan keseriusan amalan, yakni berjalan menuju kepada-Nya. 


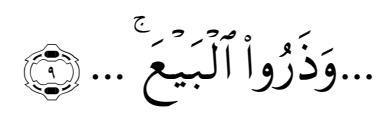

"Dan tinggalkanlah jual beli"

Maksudnya bersegeralah kalian (berangkat) untuk mengingat Allah dan tinggalkanlah jual beli jika diseru untuk mengejakan shalat. Oleh karena itu, para ulam sepakat mengharamkan jual beli yang dilakukan setelah suara adzan kedua dikumandangkan. Kemudian mereka berbeda pendapat tentang sah tidaknya jual beli yang dilakukan ketika mendengar suara adzan. Mengenai yang terakhir ini terdapat dua pendapat. Wallaahu a"lam.

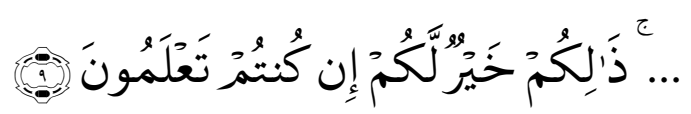

"Yang demikian itu lebih baik bagimu jika kamu mengetahui"

Maksudnya, Tindakan kalian meninggalkan jual beli dan keputusan kalian berangkat untuk berdzikir kepada Allah dan melaksanakan shalat adalah lebih baik bagi kalian di dunia dan akhirat, jika kalian memang mengetahui

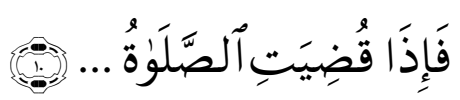

" Dan jika telah menunaikan shalat." Maksudnya telah selesai mengerjakannya.
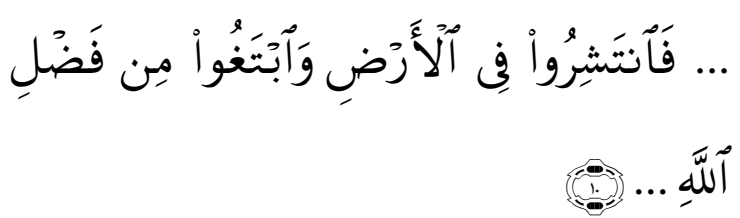

"Maka bertebarkanlah kamu di bumi dan carilah karunia Allah."

Maksudnya, ketika Allah Allah melarang mereka berjual beli setelah terdengar suara adzan dan memerintahkan mereka untuk berkumpul, maka Allah mengizinkan mereka setelah selesai menunaikan shalat untuk bertebaran di muka bumu dan mencari karunia Allah Ta"ala.

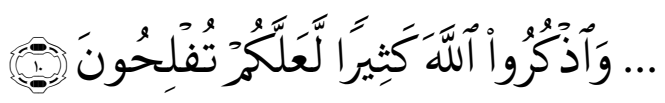

"Dan berdzikirlah kamu kepada Allah banyak-banyak supaya kamu beruntung." Maksudnya, ketika ketika kalian sedang berjual beli, dan pada saat kalian mengambil dan memberi, hendaklah kalian berdzikir kepada Allah sebanyakbanyaknya dan janganlah kesibukan dunia melupakan kalian dari hal-hal yang bermanfaat untuk kehidupan akhirat.

\section{Tabel 3}

Tafsir Ibnu Katsir Surat Al Jumuah Ayat 9-10

\begin{tabular}{|c|c|c|}
\hline Ayat & Terjemahan & Tafsir Ibnu Katsir \\
\hline 1 & $\begin{array}{l}\text { apabila } \\
\text { diseru untuk } \\
\text { menunaika } \\
\text { n shalat } \\
\text { Jum'at }\end{array}$ & $\begin{array}{l}\text { Yang dimaksud } \\
\text { dengan seruan } \\
\text { ini adalah seruan } \\
\text { kedua yang } \\
\text { dilakukan di } \\
\text { hadapan } \\
\text { rasulullah jika }\end{array}$ \\
\hline
\end{tabular}




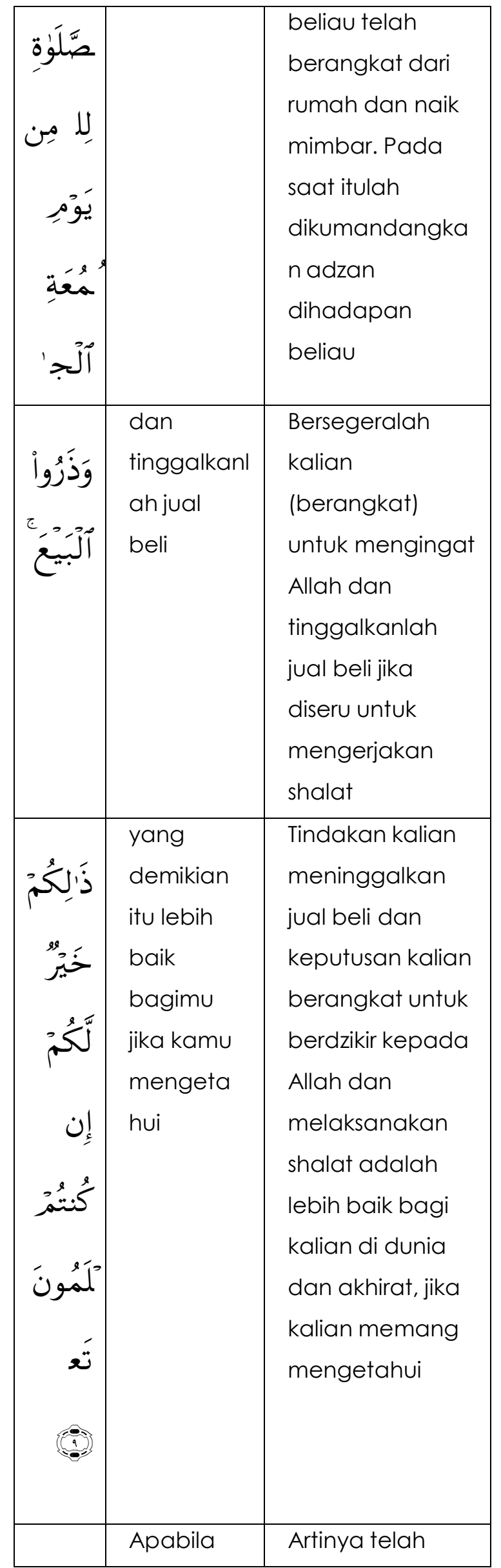

\begin{tabular}{|c|c|c|}
\hline فَإِذَا & $\begin{array}{l}\text { telah } \\
\text { ditunaikan } \\
\text { shalat }\end{array}$ & $\begin{array}{l}\text { selesai } \\
\text { mengerjakan } \\
\text { shalat }\end{array}$ \\
\hline صََّلَوُةُ & & \\
\hline و مِن & $\begin{array}{l}\text { maka } \\
\text { bertebarla } \\
\text { h kamu } \\
\text { di } \\
\text { bumi } \\
\text { dan } \\
\text { carila } \\
\text { h } \\
\text { karuni } \\
\text { a } \\
\text { Allah }\end{array}$ & $\begin{array}{l}\text { Ketika Allah } \\
\text { melarang } \\
\text { mereka berjual } \\
\text { beli setelah } \\
\text { terdengar suara } \\
\text { adzan dan } \\
\text { memerintahkan } \\
\text { mereka untuk } \\
\text { berkumpul, } \\
\text { maka Allah } \\
\text { mengizinkan } \\
\text { mereka setelah } \\
\text { selesai } \\
\text { menunaikan } \\
\text { shalat untuk } \\
\text { bertebaran di } \\
\text { muka bumi dan } \\
\text { mencari karunia } \\
\text { Allah }\end{array}$ \\
\hline مَذْرَعُواْ & $\begin{array}{l}\text { dan } \\
\text { ingatlah } \\
\text { Allah } \\
\text { banyak- } \\
\text { banyak } \\
\text { supaya } \\
\text { kamu } \\
\text { beruntun } \\
\text { g }\end{array}$ & $\begin{array}{l}\text { Ketika kalian } \\
\text { sedang berjual } \\
\text { beli, dan pada } \\
\text { saat kalian } \\
\text { mengambil dan } \\
\text { memberi, } \\
\text { hendaklah kalian } \\
\text { mengingat } \\
\text { (berdzikir) } \\
\text { kepada Allah } \\
\text { sebanyak- }\end{array}$ \\
\hline
\end{tabular}




\begin{tabular}{|c|c|}
\hline لَّحُونَ & $\begin{array}{l}\text { banyaknya dan } \\
\text { janganlah } \\
\text { kesibukan dunia } \\
\text { melupakan } \\
\text { kalian dari hal- } \\
\text { hal yang } \\
\text { bermanfaat } \\
\text { untuk kehidupan } \\
\text { akhira† }\end{array}$ \\
\hline
\end{tabular}

Sumber: Abdullah (2007), diolah kembali

b. Tafsir Al-Qurthubi Surat Al Jumuah Ayat 9-10 (Al Qurthibi dalam Jamal, 2012)

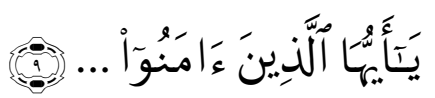

"Hai orang-orang yang beriman."

Allah Subhanahu Wata"ala berfirman untuk kaum mukminin secara khusus tentang hari Jum"at, tanpa menyebut orang-orang kafir, sebagai bentuk kemuliaan dan penghormatan terhadap mereka.

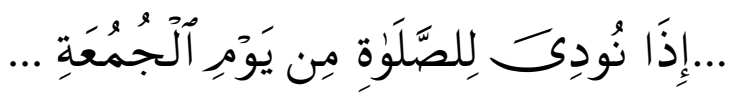

"Apabila diseru untuk menunaikan shalat pada hari Jum'at."

Ibnul Arabi rahimahullah berkata, "Sebutan „pada hari Jum"at" memberi faedah tersebut. Sebab, panggilan azan yang khusus pada hari itu adalah panggilan untuk shalat tersebut (shalat Jum"at) Adapun shalat lainnya bersifat umum pada seluruh hari. Kalaulah yang dimaksud oleh ayat ini bukan panggilan azan Jum"at, maka pengkhususan sebutan Jum"at dan penyandaran hari tersebut kepadanya menjadi tidak bermakna dan tidak berfaedah."

Al-Imam asy-Syafi"i rahimahullah berkata, "Ukuran seseorang mendengar azan adalah jika seorang muazin suaranya lantang, dalam kondisi hening, dan angin bertiup tenang, muazin berdiri di pagar batas kampung." Al-Imam Ahmad dan Ishaq rahimahumallah berkata, "Wajib shalat Jum"at bagi yang mendengar panggilan adzan."

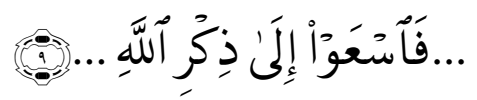

"Bersegeralah menuju zikrullah."

Ibnul „Arabi rahimahullah berkata, "Yang sahih, semua itu adalah wajib, dan awalnya adalah khutbah. Inilah yang menjadi pendapat para ulama kami, selain Ibnul Majisyun yang berpendapat sunnah. Dalil yang menunjukkan wajibnya; bahwa bersegera menuju zikrullah mengharamkan jual beli. Kalaulah bukan karena wajibnya, tentu jual beli tidak akan diharamkan. Sebab, sesuatu yang mustahab tidak bisa mengharamkan sesuatu yang hukumnya mubah."

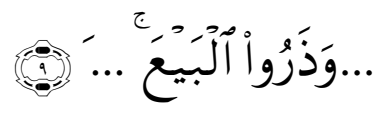

"Tinggalkan jual beli." 
Ibnul Arabi rahimahullah berkata, "Alasan jual beli dilarang adalah karena menyibukkan (dari bersegera menuju shalat Jum"at). Maka dari itu, setiap perkara yang menyibukkan dari pelaksanaan Jum"at, yaitu seluruh jenis akad, diharamkan secara syariat dan dibatalkan akadnya sebagai bentuk hukuman."

\section{Gambaran Kawasan Ampel}

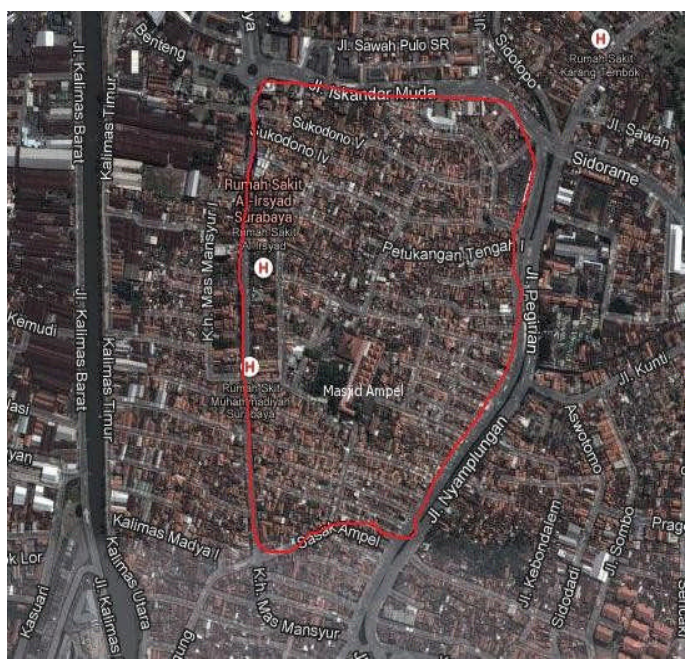

Sumber: Google earth, 2014 (diakses 9 Januari 2014)

\section{Gambar 1.}

Peta Satelit Kawasan Ampel Surabaya

Masjid Ampel merupakan pusat ibadah dan pusat dakwah Islam yang dirintis oleh Sunan Ampel, kawasan ini menjadi penting sebagai tempat ibadah atau kawasan religi, pusat pendidikan kelslaman, serta sarana pemukiman dan pariwisata religius. Keberadaan Masjid Ampel pusat penyebaran agama Islam menjadikan kawasan Ampel ditetapkan pemerintah sebagai pusat wisata religi di Surabaya. Pada kawasan Ampel ini terdapat beberapa wisata religi seperti Masjid Ampel, Makam Sunan Ampel, Makam KH Mas Mansyur, Makam Boto Putih dan Pasar Sasak Ampel Suci.

Bulan Ramadhan (menjelang idul fitri) dan bulan Haji (Idul Adha) kawasan Ampel menjadi sangat padat oleh pendatang dari berbagai daerah. Jumlah pengunjung bahkan bisa lebih banyak hingga dua kali lipat dibandingkan dengan hari biasa. Hal ini disebabkan karena budaya di Indonesia khususnya umat Islam bulan Ramadhan (menjelang Idul Fitri) identik dengan "bermalam" di Masjid dan menjelang Idul Fitri banyak belanja dan memberi oleh-oleh kesanak famili mereka dalam bentuk perlengkapan sholat, minyak wangi maupun baju baru. Pada bulan Haji (Idul Adha) orang-orang yang pulang dari haji punya kebiasaan memberikan oleh-oleh kepada tamu yang mengunjungi mereka. Tidak hanya beribadah dan berbelanja, ada juga yang ingin melihat bentuk dan arsitektur bangunan Masjid Ampel yang dibangun sejak 1421. Wisata religi Masjid Ampel memiliki bentuk bangunan yang khas dan sebagian besar bangunannya bernuansa Timur Tengah.

$$
\text { Masjid Sunan Ampel yang }
$$
dibangun oleh Sunan Ampel yang dibantu oleh sahabat karibnya yakni Mbah Sleh dan Mbah Sonhaji serta para santrinya sekitar tahun 1421. Tempat ibadah seluas $120 \times 180$ meter persegi ini dibangun dengan memanfaatkan sebidang tanah di desa Ampel, yang saat ini menjadi kelurahan Ampel, kecamatan 
Semampir, sekitar 2 kilometer sebelah timur Jembatan Merah. Walaupun beberapa kali mengalami renovasi namun keaslian bangunan masjid ampel masih tetap terjaga, hal ini terbukti dengan keenam belas tiang utamanya yang berupa kayu jati masing-masing panjangnya tujuh belas meter dan diameter enam puluh sentimeter.

Kawasan Ampel dihuni oleh penduduk etnis Jawa, etnis Cina, etnis Madura dan keturunan Arab atau Timur Tengah. Komunitas keturunan Arab atau Timur Tengah sangat mendominasi kawasan Ampel, karena itu orang dengan perawakan khas Timur Tengah banyak terdapat di kawasan Ampel. Banyak diantara pedagang yang menjual barang-barang yang bernuansa Timur Tengah mulai dari minyak wangi, perlengkapan haji, kurma, kitab-kitab pondok, kitab Beirut dan Alquran. Tidak hanya itu saja, nuansa Timur Tengahnya begitu terasa dengan banyaknya yang berjualan masakan khas Timur Tengah seperti nasi kebuli, roti maryam, kambing oven dan makanan-makanan yang berbau Timur Tengah lainnya. Keberadaan warga keturunan Arab di kawasan Ampel tidak terlepas dari sejarah Sunan Ampel, yang merupakan keturunan Arab.

Banyaknya para peziarah di kawasan Ampel menjadi alasan utama semua pedagang untuk membuka usaha atau be rdagang di kawasan masjid Ampel. Toko-toko tersebut berdagang mulai perlengkapan haji, alat tulis kantor, kitab-kitab Islami dan minyak wangi yang umumnya barang-barang tersebut banyak dibutuhkan oleh para peziarah yang datang di Makam Sunan Ampel.

Kesibukan pedagang dimulai sekitar jam sembilan sampai dengan menjelang maghrib, akan tetapi aktivitas jual beli ketika siang (dhuhur) cenderung menurun jika dibandingkan menjelang sore (setelah dhuhur). Hal ini dikarenakan mayoritas pedagang meluangkan waktu tersebut untuk istirahat dan ibadah. Keramaian setelah siang (dhuhur) ini diakibatkan oleh banyaknya para pembeli/peziarah yang "turun" dari masjid setelah melakukan ibadah untuk berbelanja barang-barang yang dibutuhkannya.

Pemahaman surat Al Jumuah ayat 9-10 menurut pedagang

\section{Tabel 4}

Pemahaman Surat Al-Jumu'ah ayat 9-10

\begin{tabular}{|c|l|l|}
\hline $\begin{array}{c}\text { Infor } \\
\text { man }\end{array}$ & $\begin{array}{c}\text { Pemahama } \\
\text { n Surat Al } \\
\text { Jumuah } \\
\text { Ayat 9-10 }\end{array}$ & Keterangan \\
\hline Infor & ketika & Informan \\
man & mendengar & memaham \\
Perta & panggilan & isurat Al \\
ma & adzan & Jumuah \\
& tinggalkan jual & ayat 9-10. \\
& beli dan & Informan \\
& melaksanakan & juga \\
& sholat Jum"at. & menjelask \\
\hline
\end{tabular}




\begin{tabular}{|c|c|c|}
\hline & $\begin{array}{l}\text { Tidak hanya } \\
\text { untuk sholat } \\
\text { Jum"at saja. }\end{array}$ & $\begin{array}{l}\text { an surat } \\
\text { Al } \\
\text { Jumuah } \\
\text { ayat 9-10 } \\
\text { tidak } \\
\text { hanya } \\
\text { untuk } \\
\text { sholat } \\
\text { Jum"at } \\
\text { saja, tapi } \\
\text { diterapka } \\
\text { n } \\
\text { kesemua } \\
\text { sholat } \\
\text { wajib } 5 \\
\text { waktu }\end{array}$ \\
\hline $\begin{array}{l}\text { Infor } \\
\text { man } \\
\text { kedu } \\
\text { a }\end{array}$ & $\begin{array}{l}\text { dianjurkannya } \\
\text { meninggalkan } \\
\text { kegiatan } \\
\text { apapun } \\
\text { termasuk jual } \\
\text { beli dan } \\
\text { segera } \\
\text { menjalankan } \\
\text { sholat Jum"at. }\end{array}$ & $\begin{array}{l}\text { Informan } \\
\text { memaham } \\
\text { i surat Al } \\
\text { Jumuah } \\
\text { ayat 9-10. } \\
\text { Menurut } \\
\text { informan } \\
\text { surat ini } \\
\text { hanya } \\
\text { untuk } \\
\text { sholat } \\
\text { Jum"at } \\
\text { saja }\end{array}$ \\
\hline $\begin{array}{l}\text { Infor } \\
\text { man } \\
\text { Ketig } \\
\text { a }\end{array}$ & $\begin{array}{l}\text { Informan tidak } \\
\text { memahami } \\
\text { surat Al } \\
\text { Jumuah ayat } \\
\text { 9-10 }\end{array}$ & $\begin{array}{l}\text { Informan } \\
\text { tidak } \\
\text { memaham } \\
\text { i, hal ini } \\
\text { dikarena } \\
\text { kan } \\
\text { masih } \\
\text { bukanya }\end{array}$ \\
\hline
\end{tabular}

\begin{tabular}{|c|c|c|}
\hline & & $\begin{array}{l}\text { toko } \\
\text { ketika } \\
\text { sholat } \\
\text { Jum"at. } \\
\text { informan } \\
\text { dan } \\
\text { pegawai } \\
\text { laki- } \\
\text { lakinya } \\
\text { melaksan } \\
\text { akan } \\
\text { sholat } \\
\text { Jum"at, } \\
\text { sedangk } \\
\text { an } \\
\text { perempu } \\
\text { an } \\
\text { menjaga } \\
\text { toko. }\end{array}$ \\
\hline $\begin{array}{l}\text { Infor } \\
\text { man } \\
\text { Kee } \\
\text { mpat }\end{array}$ & $\begin{array}{l}\text { agar setiap } \\
\text { orang yang } \\
\text { beriman ketika } \\
\text { mendengar } \\
\text { panggilan } \\
\text { adzan } \\
\text { hendaklah } \\
\text { melaksanak } \\
\text { an sholat } \\
\text { Jum"at dan } \\
\text { tinggalkanla } \\
\text { h semua } \\
\text { aktifitas } \\
\text { untuk sholat } \\
\text { Jum"at, jika } \\
\text { selesai } \\
\text { dilakukan } \\
\text { sholat }\end{array}$ & $\begin{array}{l}\text { Informan } \\
\text { memaham } \\
\text { isurat Al } \\
\text { Jumuah } \\
\text { ayat 9-10. } \\
\text { Menurut } \\
\text { informan } \\
\text { surat ini } \\
\text { hanya } \\
\text { untuk } \\
\text { sholat } \\
\text { Jum"at } \\
\text { saja }\end{array}$ \\
\hline
\end{tabular}




\begin{tabular}{|c|c|c|}
\hline & $\begin{array}{l}\text { Jum"at } \\
\text { maka } \\
\text { berusaha } \\
\text { kembali } \\
\text { mencari } \\
\text { rezeki di } \\
\text { bumi yakni } \\
\text { bekerja } \\
\text { kembali }\end{array}$ & \\
\hline $\begin{array}{l}\text { Infor } \\
\text { man } \\
\text { kelim } \\
\text { a }\end{array}$ & $\begin{array}{l}\text { diwajibkannya } \\
\text { meninggalkan } \\
\text { aktifitas } \\
\text { apapun } \\
\text { bahkan jual } \\
\text { beli ketika } \\
\text { diserukannya } \\
\text { adzan sholat } \\
\text { Jum"at dan } \\
\text { kembali } \\
\text { mencari } \\
\text { karunia Allah } \\
\text { setelah } \\
\text { melaksanaka } \\
\text { n sholat } \\
\text { Jum"at, dan } \\
\text { selalu } \\
\text { berdzikir } \\
\text { ketika } \\
\text { bekerja }\end{array}$ & $\begin{array}{l}\text { Informan } \\
\text { memaham } \\
\text { i surat Al } \\
\text { Jumuah } \\
\text { ayat 9-10 } \\
\text { Informan } \\
\text { juga } \\
\text { menjelask } \\
\text { an surat } \\
\text { Al } \\
\text { Jumuah } \\
\text { ayat 9-10 } \\
\text { tidak } \\
\text { hanya } \\
\text { untuk } \\
\text { sholat } \\
\text { Jum"at } \\
\text { saja, tapi } \\
\text { diterapka } \\
\text { n } \\
\text { kesemua } \\
\text { sholat } \\
\text { wajib } 5 \\
\text { waktu }\end{array}$ \\
\hline $\begin{array}{l}\text { Infor } \\
\text { man } \\
\text { Keen } \\
\text { am }\end{array}$ & $\begin{array}{l}\text { dianjurkannya } \\
\text { kembali } \\
\text { bekerja } \\
\text { setelah }\end{array}$ & $\begin{array}{l}\text { Informan } \\
\text { memaham } \\
\text { i surat Al } \\
\text { Jumuah }\end{array}$ \\
\hline
\end{tabular}

\begin{tabular}{|c|c|c|}
\hline & $\begin{array}{l}\text { melakukan } \\
\text { ibadah } \\
\text { sholat } \\
\text { Jum"at, } \\
\text { selalu } \\
\text { berusaha } \\
\text { berbuat } \\
\text { amal dan } \\
\text { saat bekerja } \\
\text { maupun } \\
\text { tidak bekerja } \\
\text { berusaha } \\
\text { untuk } \\
\text { mengingat } \\
\text { Allah }\end{array}$ & $\begin{array}{l}\text { ayat 9-10. } \\
\text { Menurut } \\
\text { informan } \\
\text { surat ini } \\
\text { hanya } \\
\text { untuk } \\
\text { sholat } \\
\text { Jum"at } \\
\text { saja }\end{array}$ \\
\hline $\begin{array}{l}\text { Infor } \\
\text { man } \\
\text { Ketuj } \\
\text { uh }\end{array}$ & $\begin{array}{l}\text { Informan tidak } \\
\text { memahami } \\
\text { surat Al } \\
\text { Jumuah ayat } \\
\text { 9-10 }\end{array}$ & $\begin{array}{l}\text { Informan } \\
\text { tidak } \\
\text { memaham } \\
\text { i, hal ini } \\
\text { dikarena } \\
\text { kan } \\
\text { masih } \\
\text { bukanya } \\
\text { toko } \\
\text { ketika } \\
\text { sholat } \\
\text { Jum"at } \\
\text { dilaksana } \\
\text { kan, } \\
\text { informan } \\
\text { melaksan } \\
\text { akan } \\
\text { sholat } \\
\text { Jum"at, } \\
\text { sedangk } \\
\text { an } \\
\text { pegawai }\end{array}$ \\
\hline
\end{tabular}




\begin{tabular}{|c|c|c|}
\hline & & $\begin{array}{l}\text { perempu } \\
\text { annya } \\
\text { menjaga } \\
\text { toko. }\end{array}$ \\
\hline $\begin{array}{l}\text { Infor } \\
\text { man } \\
\text { Kede } \\
\text { lapa } \\
\mathrm{n}\end{array}$ & $\begin{array}{l}\text { Menjelaskan } \\
\text { tentang terjadi } \\
\text { di hari } \\
\text { Jum"at }\end{array}$ & $\begin{array}{l}\text { Informan } \\
\text { tidak } \\
\text { memaham } \\
\text { i surat Al } \\
\text { Jumuah } \\
\text { ayat 9-10 }\end{array}$ \\
\hline $\begin{array}{l}\text { Infor } \\
\text { man } \\
\text { Kese } \\
\text { mbila } \\
\text { n }\end{array}$ & $\begin{array}{l}\text { Mengajak } \\
\text { bagi orang- } \\
\text { orang yang } \\
\text { beriman jika } \\
\text { sudah datang } \\
\text { panggilan } \\
\text { untuk } \\
\text { menunaikan } \\
\text { sholat maka } \\
\text { bersegeralah } \\
\text { untuk } \\
\text { mengingat } \\
\text { Allah dan } \\
\text { tinggalkanlah } \\
\text { jual beli maka } \\
\text { jika kamu } \\
\text { mengerti ini } \\
\text { baik untukmu }\end{array}$ & $\begin{array}{l}\text { Informan } \\
\text { memaham } \\
\text { i surat Al } \\
\text { Jumuah } \\
\text { ayat 9-10. } \\
\text { Menurut } \\
\text { informan } \\
\text { surat ini } \\
\text { hanya } \\
\text { untuk } \\
\text { sholat } \\
\text { Jum"at } \\
\text { saja }\end{array}$ \\
\hline
\end{tabular}

Sumber : Hasil Wawancara (diolah)

Dari sembilan informan terdapat enam informan yang memahami surat $\mathrm{Al}$ Jumuah ayat $9-10$ dan tiga informan yang tidak memahami surat Al Jumuah ayat 9-10. Dari enam informan yang memahami surat Al Jumuah ayat 9-10 semua menjelaskan bahwa dianjurkannya meninggalkan jual beli ketika panggilan adzan telah diserukan dan kembali bekerja setelah selesai melaksanakan ibadah shalat Jum"at.

Dampak Pemahaman dan Pengamalan Surat Al Jumuah ayat 9-10 pada

Rezeki Pedagang

Tabel 5

\section{Dampak Positif Terhadap Rezeki Ketika Mengamalkan Sholat Jum'at}

\begin{tabular}{|c|c|c|}
\hline No. & Informan & Keterangan \\
\hline 1. & Informan Pertama & $\begin{array}{l}\text { Ada, tapi tidak secara } \\
\text { langsung }\end{array}$ \\
\hline 2. & Informan Kedua & Ada \\
\hline 3. & Informan Ketiga & $\begin{array}{l}\text { Ada, tapi tidak secara } \\
\text { langsung }\end{array}$ \\
\hline 4. & Informan Keempat & $\begin{array}{l}\text { Ada, tapi tidak secara } \\
\text { langsung }\end{array}$ \\
\hline 5. & Informan Kelima & Ada \\
\hline 6. & Informan Keenam & Ada \\
\hline 7. & Informan Ketujuh & $\begin{array}{l}\text { Sholat atau tidaknya tidak } \\
\text { selalu ada pengaruh Positif } \\
\text { atau negatif terhadap } \\
\text { rezeki, tapi lebih kearah } \\
\text { kepantasan tata cara } \\
\text { meminta rezeki. }\end{array}$ \\
\hline 8. & Informan kedelapan & Ada \\
\hline 9. & Informan kesembilan & $\begin{array}{l}\text { Ada. Tidak hanya rezeki } \\
\text { yang berdampak } \\
\text { positif,keimanan kita juga } \\
\text { berdampak positif karena } \\
\text { mendengarkankhotbah dari } \\
\text { imam. }\end{array}$ \\
\hline
\end{tabular}

Sumber: Hasil Observasi (2013)

Dengan mengamalkan sholat Jum"at berdampak positif terhadap rezeki, meskipun datangnya rezeki tidak secara langsung. Menurut informan ke-sembilan dampak positif tidak hanya terhadap rezeki saja, akan tetapi berdampak kepada semakin tingginya keimanan dikarenakan dari sholat Jum"at dan mendengar khotbah dari khotib yang 
berisi nasehat-nasehat fatwa tentang keagamaan. Selain itu yang tidak kalah pentingnya adalah bersedekah. Dengan bersedekah Allah akan melancarkan setiap usaha yang telah dikerjakan, sedekah dapat membuka pintu rezeki yang tidak disangka-sangka oleh manusia. Dengan bersedekah dapat menghapus harta-harta kotor yang diperoleh selama ini. Meskipun sedekah bersifat tidak wajib.

\section{PENUTUP}

Secara singkat dan sederhana tulisan ini sudah mencoba mendeskripsikan tentang pemahaman dan pengamalan surat Al Jumuah pada pedagang di lingkungan masjid Ampel Surabaya. Tulisan ini memang masih sangat terbatas pada surat Al Jumuah ayat 9-10 terhadap sembilan informan

Dari tulisan ini dapat diambil kesimpulan bahwa bahwa para informan memahami surat Al Jumuah ayat 9-10 sudah baik ini dapat dilihat dari kesembilan informan yang diteliti enam informan menjelaskan bahwa dianjurkannya meninggalkan jual beli ketika panggilan adzan telah diserukan dan kembali bekerja setelah selesai melaksanakan ibadah shalat Jumat. Dari sembilan informan hanya informan pertama dan kelima yang menyatakan bahwa surat Al Jumuah tidak hanya untuk sholat Jum"at, akan tetapi untuk ke semua panggilan adzan sholat wajib lima waktu. Pedagang di lingkungan masjid Ampel Surabaya hampir seluruhnya mengamalkan surat Al Jumuah ayat 9-
10 dengan baik ini dapat dilihat dari kesembilan informan yang diteliti tujuh informan mengamalkan dan dua yang tidak mengamalkan. Dari dua informan yang tidak mengamalkan mereka beralasan karena tidak memahami surat Al Jumuah ayat 9-10 dengan baik.

\section{DAFTAR PUSTAKA}

Abdullah, M. (2007). Tafsir Ibnu Katsir. Bogor: Pustaka Imam Asy-Syafi"i.

Al-Ghazali, (2008). Mutiara Ihya Ulumuddin. Terjemahan oleh: Irwan Kurniawan, Bandung: Mizan.

Asqalani, Ibnu Hajar. 1997. Fathul Baari: Penjelasan Kitab Shahih AlBukhari. Jilid ke-12.

Jakarta: Pustaka Azam.

Badri, Muhammad Arifin. 2008. Sifat Perniagaan Nabi: Panduan Praktis Fiqih Perniagaan Islam. Bogor: Pustaka Darul Ilmi.

$\begin{array}{lll}\text { Jual } & \text { Beli dalam } & \text { Ajaran } \\ \text { Islam, (Online) } & & \end{array}$
http://pengusahamuslim.com/prinsip-jualbeli-dalam-ajaran-Islam.html. Diakses 13 November 2012.

Baqi, Muhammad Fuad Abdul. Tanpa Tahun. Himpunan Hadits Shahih Disepakati oleh

Bukhari dan Muslim. Terjemahan oleh Salim Bahreisy. 2003. Surabaya: PT. Bina IImu. BPS. 2010. (online) www.bps.go.id. 
Elfindri, dkk. 2010. "Minang Entrepreneurship, Filosofi Dan Rahasia Sukses Etis Minang

Membangun Karakter Kewirausahaan". Jakarta, Badouse Media.

Fairman, Muhammad Khair. Etika Muslim Sehari-Hari. Terjemahan oleh Bigadarin. 2002.

Jakarta: Pustaka Al-kautsar.

Jamal, Abu Muawiyah Askari. 2012. Tafsir "Bersegera Menuju Zikrullah", (online), http://asysyariah.com/tafsirbersegera-menuju-zikrullah.html. Diakses pada tanggal 2 Februari 2014.

Khutbah. 2010, 16 Juli. Jihad Melalui Usaha adalah Lebih. Vol:343/7-10/C.

Maulan, R. 2009. Makna Tawakal, (online), http://www.eramuslim.com/syari ah /tafsir- hadits/maknatawakal.htm\#.UP7qARlazNU.

Diakses pada tanggal 21 Januari 2013.

Qardhawi, Yusuf. 2011. Halal dan Haram. Jakarta: Robbani Press.

Rachbini, Didik, J.2002. Ekonomi politik: Paradigma dan teori pilihan publik. Jakarta: Ghalia Indonesia. Rich dan Laode, 2012. Rasulullah's Business School. Jakarta: Ihwah Publishing House.

Sa'di, Abdurrahaman, et al. Tanpa Tahun. Figh Jual-Beli: Panduan Bisnis Syariah. Edisi

Pertama. Terjemahan oleh Abdullah. 2008. Jakarta: Senayan Publishing.
Tuasikal, Muhammad Abduh. 2012. Larangan Jual Beli Saat Shalat Jum"at Toko-Toko. (online).http://muslim.or.id/fiqhdan-muamalah/larangan-jualbeli-saat-shalatjum\%E2\%80\%99at.html. Diakses pada tanggal 18 januari 2013.

Wibowo, Endro. 2010. Proses Manajemen Risiko Pembiayaan Murabahah pada BMT Amanah

Ummah. Skripsi tidak diterbitkan. Fakultas Ekonomi dan Bisnis, Universitas Airlangga. Yusuf, Muhammad MA. Dkk. 2004. Studi Kitab Tafsir: Menyuarakan Teks Yang Bisu, Yogyakarta: Teras 